\title{
E-Estonia: The e-government cases of Estonia, Singapore, and Curaçao
}

\author{
Dr. Miguel Goede
}

\begin{abstract}
Purpose - The purpose of this article is to study how Estonia became one of the frontrunners of e-government and to answer the questions: how did Estonia do it, and can other countries do it too? The case of e-Estonia is compared to the cases of Singapore and Curaçao.

Methodology - The paper draws on literature concerning e-Estonia and e-government. Estonia and Singapore are compared, and an assessment is done to see if the island of Curaçao can implement e-government like Estonia and Singapore did.

Findings - All countries are unique and have to find their own path towards egovernment. E-government is not a destination but a journey. Although all paths are unique, there are similarities, and countries can learn from each other.

Originality - There are not many studies comparing e-Estonia to Singapore or other smart nations. This study also presents some lessons other countries might learn and apply on their own journey.

Keywords - Estonia, e-Estonia, Singapore, smart nation, Curaçao, public governance, egovernance, ICTs

Conclusions - Although e-government is an individual journey and a unique path, countries can learn a lot by studying others like Estonia and Singapore.

Paper type - Comparative study
\end{abstract}

\section{INTRODUCTION}

In 1918 Estonia gained its independence from the Bolsheviks. In 1940 the Soviet Union subsumed the country. In 1991 Estonia regained independence. The country now knows two ethnic groups: Estonians and former Soviet colonists and their descendants. Now Estonia is starting to play a role on the global stage as one of the frontrunners regarding ICT and especially e-government (Taagepera, 2018; Tham, 2018). To illustrate this, the Skype application was originally developed by Estonians in 2003. The journey of Estonia started by refusing Finland's donation of an old analog telephone exchange for free. In 1998 all schools were connected to the internet (Keen, 2018), and in 2000 internet access was declared a human right.

Estonia has the lowest business-tax rate of the European Union. Innovation has become part of the DNA of Estonia. There are many startups, and talent finds its way to Estonia. They are currently testing driverless cars. Startups hardly leave a trace because much is done digitally (Heller, 2017; Menkhoff, 2018).

In 2002 Estonia became the first country to introduce the widespread use of electronic identification cards. This allowed citizens to digitally identify themselves and sign documents. It was all strongly regulated within a legal framework focused on security and the protection of personal data. This has created a platform to build new e-services by using already stored data in the state's databases. Technology was the primary enabler. The X-Road was created as a secure internet-based data exchange layer that enables different information systems to communicate and exchange data with each other. All this was achieved in a joint effort by the public and private sector: mainly banks and the telecom industry. All stakeholders wanted to replace the physical with the digital (Kristjan, 2015; World Bank, 2018). 
The digital security of the X-Road is a blockchain technology called K.S.I. (Heller, 2017). The system is backed up on a server in Luxembourg, a digital diplomatic mission. It allows Estonia to function even in the event of an invasion with no interruption.

In this article we seek the answer to the following questions:

1. Who is Estonia?

2. What did they do regarding e-government?

3. Why did they do this?

4. How did Estonia do this?

5. Why did Estonia succeed?

6. Can this success be replicated by countries?

\section{Box 1: Basic facts on Estonia}

Population: $1,294,236$

Area: 45,227 km² Currency: Euro (since 2011)

Capital: Tallinn

Administrative divisions: 15 counties and 213 municipal districts, including 30 towns and 183 parishes (Kristjan, 2015).

- Internet, high-bandwidth connectivity

- $75 \%$ of the population uses the internet regularly (2009)

- $67 \%$ of households have a PC, and 91\% are connected to the internet (Tiik and Ross, 2010)

Compulsory health insurance paid by the employer

- Health insurance tax $13 \%$

- Health care costs make up 5\% of GDP

- Income tax $21 \%$ (flat tax)

- Healthcare providers are private, municipal, or governmental.

- Family doctors (private companies)

- Hospitals (shared companies or foundations) (Tiik and Ross, 2010)

\section{METHODOLOGY}

The methodology is based on the comparison of three countries that have either introduced or are considering ICT solutions to their state and public management systems: Estonia, Singapore, and Curaçao.

\section{LITERATURE OVERVIEW}

Modern information and communication technologies are the new DNA of societies, which today are network societies (Castells, 1996). This is manifested in all domains, including the public domain in the form of e-government. The embracement by governments of novel and innovative solutions for repetitive tasks such as providing information from the public register, verifying ownership of property, and even e-voting as in the case of Estonia has become the norm (Maaten, 2004).

The theory puts considerable emphasis on the growing tendency for e-government and electronic service distribution, the embracing of e-government instruments to accelerate regulatory reform, and the capacity of empowered communities and cooperative governance for sustainable development (Nica, 2015).

There are several reasons for embracing e-government. For example, Ionescu (2015) shows how e-government can be helpful in curbing the corruption in public administration 
(Kozubíková et al., 2017). Some indicate that a digital government is also a tool for sustainable development (Menkhoff, 2018). They point out, for example, that there is less traveling to government offices by citizens and much time is saved by all. And this is just the beginning as more and more governments are developing apps to enable m-government (mobile government).

\section{ICT in public administration management in Estonia}

It is said that ninety-nine percent of government services are offered online, and not one hundred, because the government wants people to marry and divorce in person and for real estate transactions to not be digital (Heller, 2017; Tham 2018).

Estonia is a frontrunner of countries aiming to modernize the public sector and make governance more transparent. It has achieved this by the use of modern ICT in governance and the public sector. Residents and citizens can access multiple online public services such as digital identification, digital signature, internet voting, online medical services, and electronic tax filing. The services are efficient in terms of time and money for both the public and government. For example, filing taxes online takes an average no more than five minutes (Kristjan, 2017).

The government services offered online are truly accepted and used by the people. Digital identification is the backbone and is mandatory for all residents. In 2014 it was utilized more than 80 million and 35 million times for authentication and digital transactions respectively (Vassil et al., 2016). Ninety-five percent of all revenue tax statements are filed online, and 33\% of citizens engaged in online voting during the past two elections. Studies show that online government services are considered reliable and trustworthy. The people expect the services, and government bureaus view online existence not as an option but as an inevitable, essential, and strategic portion of their daily activities (Anthes, 2015).

The widely acclaimed and reported success of Estonia to convert their public services online was fundamentally driven by the widespread use of electronic ID-cards (Maaten, 2004). Since 2002, nearly 1.2 million of these personal ID documents, which are the size of credit cards, have been issued, and they allow inhabitants to digitally identify themselves and also sign for actions or documents. Identification cards are compulsory for every citizen, and they are valid for both physical and digital identification. Because of their convenient size, they can fit well into a normal wallet compared to a passport, and they are frequently used as the single identification document that individuals carry everywhere. In physical terms, they are valid for a person to be identified in Estonia, but more significantly, they are also used for traveling in many European states. Therefore, together with their principal functionality, digital identification cards are successfully employed as substitutes for traditional identification IDs (Björklund, 2016; Drechsler, 2018).

\section{What did Estonia do, and when did they do it?}

On the website www.e-estionia.com much information is presented, including a timeline of the Estonian journey and the road ahead. The current vision of e-Estonia for 2020 is that it will be a prime place to create and test smart e-solutions (Sikkut, n.d.). In this section only a few of the milestones will be elaborated upon because Estonia has done so much. ${ }^{1}$

${ }^{1}$ https://www.zdnet.com/article/e-estonia-what-is-all-the-fuss-about/ 
In Estonia innovation is led by the state. Talent leaves the private sector to join the government. An e-governance academy has been created to capture and distribute the knowledge (Heller, 2017).

\section{The road traveled}

The following timeline reflects the road Estonia took on their journey to becoming e-Estonia:

1997 e-Governance

2000 e-Tax

2001 X-Road

2002 Digital ID

2005 i-Voting

2007 Public safety

2008 Blockchain

2008 e-Health

2014 e-Residency ${ }^{2}$

\section{Future ambitions}

The following bullet list indicates the planned path toward the future of e-Estonia:

New digital nation

Cybersecurity

Data embassy

Intelligent transportation

Reporting 3.0

Cross-border data exchange

Healthcare 4.0

Digital transformation in education

Real-time economy

Industry 4.0 (e-Estonia, 2018).

\section{Building the X-Road}

In Estonia data is stored in a decentralized fashion in over 360 databases in which, via the XRoad, all information from local hosts is linked.

Estonia needed a strong digital information infrastructure. So Estonia created the X-Road: a secure data exchange for residents, public institutions, and private companies. X-Road parties share information to produce services that people can access with their e-ID. The system helps card-holding residents do everything from file taxes to review medical records to sell cars. In short, individuals retain strong oversight of their own data. (Jaffe, 2016)

\footnotetext{
2 Estonia also connected all schools to the internet in 1998. All schools were kept open after school hours so others could use the internet. The objective was to get as many people as possible on the internet.
} 


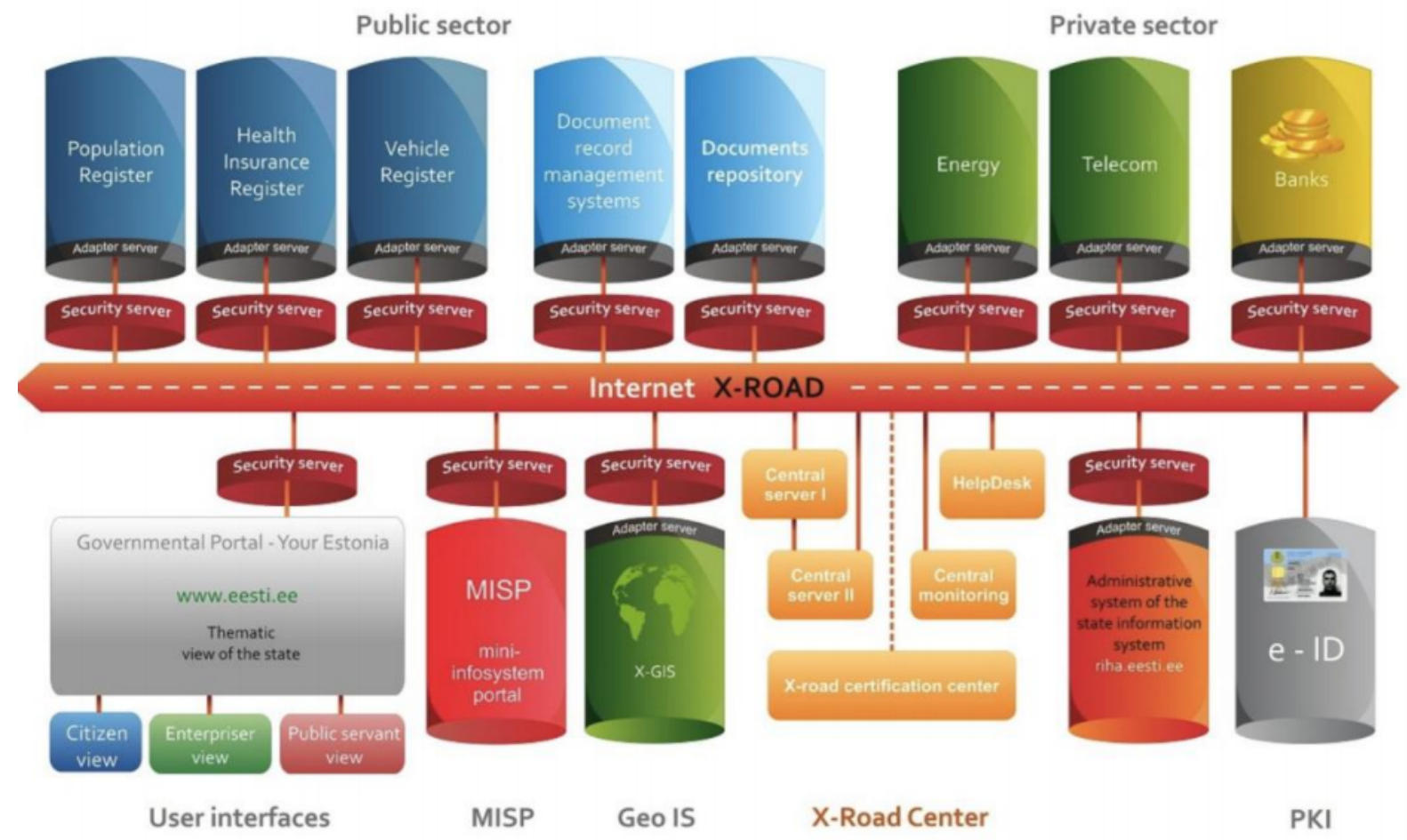

Figure 1: X-Road (Jaffe, 2016).

Facts on the X-Road:

- Aggregates 360 different databases

- 2,000 e-services

- 500 different organizations have integrated their systems into X-Road

- X-Road services were used 420,000,000 times a year (2009)

(Tiik and Ross, 2010)

A selection of the systems mentioned above are further described in the following paragraphs.

\section{E-Healthcare Estonia}

Paramedics have access via an app using X-Road to all medical records of patients in case of an emergency. It also enables telemedicine (Heller, 2017). 

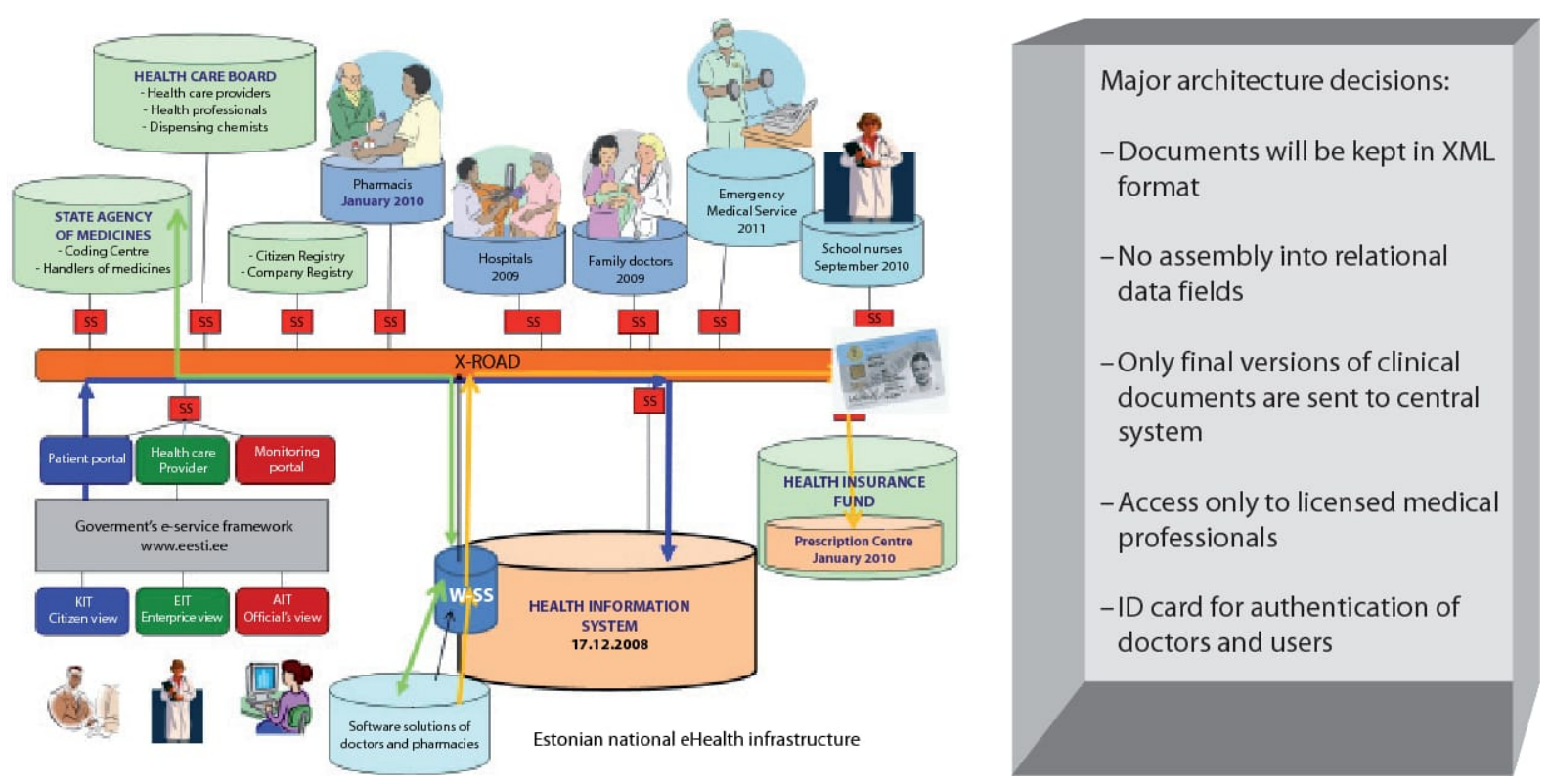

(Tiik and Ross, 2010)

In Estonia the eHealth Foundation and the Centre for Standardization is responsible for the use of health informatics standards. Since 2005, the nationwide eHealth approach has been based on four pillars: electronic health records (EHR), digital registrations, digital imaging, and digital prescriptions. The concept for the development of a national health information system was coined in 2000 with the launch of the Estonian Health Project 2015. In 2003 the Department of Health Information and Analysis was started for the practical development of the strategy of the project. The Estonian Information Society Strategy 2013 and its Implementation plan are linked to the health strategy. In 2007 a framework was launched: Knowledge-Base Estonia 2007-2013. In December 2007 the Estonian Telemedicine Association was created as a suborganization of the Finnish Society of Telemedicine and eHealth.

In general, Estonia has been or is part of several small projects, which are related to the use of telemedical applications. In December 2008 Estonian Electronic Health Record System (EHR) was created. It holds the medical files of all residents from birth to death. Since January 1 , 2009, all healthcare providers have been obliged to send an agreed-upon number of standardized medical documents, electronic notes, and electronic medical documents to it. In 2009 the National Health Development Plan (NPHS) 2009-2020 was presented by the Estonian government, and its implementation plan 2009-2012 came into effect. E-Health is one of the issues addressed. In 2010 e-Prescription services were launched, enabling medical personnel and pharmacies to monitor and manage the issuing of prescriptions. In January 2010 Estonia became a member of the International Health Terminology Standards Development Organization to enable the use of Snomed CT in connection to digital health records, health research, and other applications (Giest, 2018).

\section{Electronic ID program (E-ID)}

Estonia's e-ID card is embedded with an electronic chip and requires two pin codes. The first authenticates the user's identity. The second serves as a digital signature (Jaffe, 2016).

The digital ID-card has a microchip as well as a dual pin code that comes with the card. By using a smartcard reader and an internet-connected computer, Estonian citizens can use a digital signature (associated with PIN2) and personal authentication (associated with PIN1). Both are crucial to the growth of e-government. Most services can be accessed by using the first pin code: reviewing personal health records, inspecting the validity of motor vehicle insurance, or reviewing the number of political applicants in each district of voters. The 
second pin code is used for online approval of online transaction or to sign documents: obtaining the insurance policies, confirmation of the submission of tax declaration, or voting in elections (Kalvet, 2012; Kristjan, 2017; Arora, 2008; European Union, 2016; Jaffe, 2016; Martens, 2010).

\section{E-Voting}

Estonia is widely credited with being a pioneer in e-governance and especially e-democracy. It has frequently been expected, too, that Estonia will be the leading country for e-voting, having already introduced it for the national elections of 2003. However, in the very last changes of the respective laws, the Estonian Parliament has voted for e-voting, not for the immediate future, but only with a delay of implementation until the year 2005 (Drechsler, 2018).

In order to vote online, people are required to use their digital identification card and the computer connected to the internet equipped with the smartcard reader. Next, they need to download a voting application that is a standalone program for Estonian e-voting. Using their ID card and PIN1, the user has to first identify herself with the system, after which it checks whether the voter is eligible to vote in these elections. If affirmative, the e-voting system displays the list of candidates in the voter's district. Voters can then browse the list of candidates and decide whom to vote for. In order to cast an e-vote, the voter will choose a candidate, and after providing PIN2, the vote is electronically cast. When inserted correctly, the electronic vote is sent to the server and will be counted at an appropriate time as prescribed by the procedures of online voting (Kristjan, 2015).

The e-voting system is designed to resist some of the main challenges of remote evoting: securing voters' authentication, assuring the privacy of voters, making a re-vote possible, and making sure that the e-voting system is comprehensible enough to build the public trust (Maaten, 2004).

To vote, the voter has to go online and enter the first pin code of the e-ID for identification. A voting register confirms that the voter is eligible to vote. The voting system now knows the voter's residence and provides personalized information about the candidates in the specific district. The integrity of the vote is protected by several security mechanisms. The voter can change his or her vote online or at a physical ballot box up to Election Day. The most recent vote will be valid. This protects the voter from coercion. To prevent malware interference, software is used to check the voter's identity via a smartphone camera. The number of voters has increased each election, and once the voters have tried the online voting, they do not go back. In the elections of 2017, 31.7\% of voters voted online (Jaffe, 2016).

\section{E-Residency}

In 2014 Estonia opened up its e-government to outsiders, offering an "e-residency" that enables entrepreneurs to start a business in the country while living elsewhere (Jaffe, 2016; Keen, 2018). After approval, the credentials need to be kicked up in person at the nearest diplomatic post (Heller, 2017). Estonia was the first in the world to do so.

Over the next decade, the population of Estonia is expected to increase by more than $600 \%$, from 1.3 million to 10 million. The idea is to provide a gateway by which people outside of Estonia can make investments in Estonia, establish businesses there, and, eventually, use the country as a bridge to commerce elsewhere in the European Union (Anthes, 2015). E-residency does not offer physical residency, the right to enter the country, or the right to use the smart ID card as a travel document or physical identification. 
Why did Estonia do this? The motive is predominately economic. Estonia considers itself an enterprise that wants to increase the wealth of their people. Applications spiked during Brexit. Today the e-residency application rate exceeds the birth rate (Heller, 2017).

\title{
Success Factors of E-Estonia
}

This result was achieved by working persistently, constantly, cross-partisan, long term, across multiple changes in government. It was and still is a step-by-step development and implementation of a system. There was a high level of transparency with the system, especially if something went wrong. This has nurtured the citizens' understanding and acceptance of the system (Urban, 2018).

\section{Can others do it?}

In 2016 Japan implemented elements of e-Estonia, just like Azerbaijan, Namibia, and Finland had done. According to Estonian President Toomas Hendrik Ilves, it is not a matter of technology or scalability, but one of political will. No two systems of e-ID are alike. What they have in common, though, is that they recognize that technology can improve the lives of citizens and create the conditions for business while protecting privacy (Jaffe, 2016).

\section{Comparison with Singapore}

It can't be a coincidence that both Estonia and Singapore started their journeys after constitutional changes and gaining their independence. They both started with relatively poor economies and big challenges ahead. They both embraced state-of-the-art technology and leapfrogged in their development.

\author{
Box 2: Basic facts on Singapore \\ Population: 5,612,300 \\ Area: $721.5 \mathrm{~km}^{2}$ \\ Currency: Singapore dollar \\ Capital: Singapore \\ Administrative divisions: There are currently five Community Development Council Districts \\ Internet penetration rate: $84 \%$ \\ Compulsory health insurance paid by the employer \\ - Health insurance premium 3-10\% \\ - Health care costs make up $4.9 \%$ of GDP \\ - Income tax 0-22\% (progressive) \\ - Healthcare providers are governmental or private \\ - Family doctors (public and private) \\ - Hospitals (state-owned companies and private companies)
}

\section{E-Healthcare Singapore}

Singapore has one of the most successful and efficient healthcare systems in the world. It is supervised by the Ministry of Healthcare. It is a government-run universal healthcare system with a significant private healthcare sector. Many citizens have additional private health insurance. Since the 1990s, medical public healthcare services have been clustered in three government-owned corporations. The financing is a mixed: nationalized life insurance schemes and deductions from the compulsory savings plan. In 2011 the national Electronic Record Programme was launched. It is used by more than 280 institutions to support telehealth and telemedicine. Since 2010, Singapore has faced a shortage of beds due to an aging population. 


\section{Estonia versus Singapore}

In a sense, Estonia also has an "island effect" as it is relatively isolated from its neighbors just like islands are. Such isolation forces a small society to bond to survive and excel (Keen, 2018). In that sense, both Estonia and Singapore are islands. Both are relatively small and have little natural resources.

Both have ethnic concerns, even tensions, and national identity issues and had to strengthen the nation-building process.

While Estonia obtained independence in 1991, Singapore did so in 1965. Very early on, Singapore developed a master plan focusing early on industrialization and IT. Later the focus also included financial services, and from 2014 Singapore's aim has been to be a smart nation.

In Singapore as well as Estonia, education was a priority when embarking on the journey, and in both cases, the government led and was supported by the private sector. In the case of Estonia, the banking sector and the telecom companies led the way.

Both Estonia and Singapore focused on the private sector. In the beginning, Singapore attracted corporations, especially in ICT and, later on, the financial sector. In further stages, Singapore assisted local corporations in globalizing. In Estonia the government worked closely with the financial sector and stimulated startups.

Both Estonia and Singapore battled corruption with success. In 2017 Singapore ranked number six and Estonia number 21 on the Corruption Perception Index of Transparency International.

The two also have in common their pursuit of sustainable development. Singapore is one of the cleanest nations on earth.

One difference between Estonia and Singapore is that Estonia is more democratic and less centralized, while Singapore is the opposite.

\section{Can Curaçao do it?}

In Curaçao the term e-government was first coined in 1999 by a consultant contracted by the government. In 2010 Curaçao become an autonomous country within the Kingdom of the Netherlands as a result of constitutional reforms. Long before 2010, One Laptop Per Child was announced but was never rolled out. The state-owned telecom provider never had the mission to connect the whole island on the internet and on Wi-Fi. It remained a traditional profitmaximization-seeking company. In 2018 a privatization process started again (an attempt to privatize the company in the 1980s had failed). Curaçao was one of the first in the Caribbean region to implement voting by machine, well before 2010 , but this was reversed after a few elections because some politicians were afraid that elections were, or could be, fixed. There was not enough trust in the system. There is a project to link the databases with the basic information of citizens and businesses, but this project has never been finished.

There are several more of these projects. Although there has never been a cohesive strategy and implementation, there have been some successes. A call center was installed. Citizens can call for information regarding services and make appointments for certain government services. This has improved the service at the Civil Affairs and Vehicle Inspection Unit. In 2015 the police introduced camera surveillance, but nobody knows how effective this is, and the legal framework has not been put in place to make the images admissible in court. In 2017 e- 
tax was introduced partially but not effectively enough. Per January 1, 2019, e-tax has become mandatory.

\section{E-Health care Curaçao}

Curaçao has a very expensive and ineffective medical system. In 2019 a new national hospital will be opened after more than 165 years. The hospital will be supported by state-of-the-art technology, and it is expected to leapfrog the island into the e-health era.

Up to now, the healthcare system has been a mixed system of public and private programs and is regulated and supervised by the Ministry of Healthcare. There are several systems connecting doctors, specialists, and other providers, but there is no electronic patient file at this moment. This reduces the possibilities of improving efficiency. The island is facing challenges due to an aging population, and the current level of care is hard to maintain. Immigration from the region, especially undocumented people from Venezuela, represent a challenge for the healthcare. Change is very difficult because it is resisted by conventional interests.

\section{Curaçao versus Estonia and Singapore}

Just like Singapore and Estonia, Curaçao went through constitutional changes in 2010. The difference is that this process divided Curaçao and made governing very difficult. Corruption is on the rise. Education is deteriorating. In the new government structure, the ICT was not well embedded, and there is almost no progress. The island has not known significant economic growth for twenty years. The budget is not big enough to implement ICT projects. Investors have to wait for months for their permits.

In 2017 the new government announced the smart nation endeavor (Goede, 2018). In 2018 Cinex hosted the third smart nation conference, and Marten Kaevats, national digital advisor of the Government Office of Estonia, visited the island as a speaker. In a meeting with government officials, one of the first things he pointed out was that there was no one appointed as chief information officer and that an incremental path is not an option: Curaçao has to leapfrog toward e-government.

\section{Box 3: Basic facts on Curaçao}

Population: 160,012

Area: $444 \mathrm{~km}^{2}$

Currency: Antillean guilder

Capital: Willemstad

Administrative divisions: There are no administrative divisions

Internet penetration rate: $68.1 \%$ of the population has access to the internet

Compulsory health insurance paid by the employer

- Health insurance premium $12 \%$

- Health care costs make up 13\% of GDP

- Income tax 10.75-48.25\% (progressive)

- Healthcare providers are private, NGOs, or governmental.

- Family doctors (public and private)

- Hospitals (foundations and corporations) 


\section{CONCLUSIONS AND DISCUSSIONS}

Estonia's e-government provides a rational basis for citizens to interact with government in a way that citizens hold primacy, and it is an antidote to populism. E-government is more than a platform. It is e-democracy. It makes going back to the Greek model possible. Estonia has managed to create a digitized polis, one more democratic than Plato would have imagined. The digital platform establishes a high benchmark for transparency and accountability. Edemocracy is not primarily about representation, but about participatory democracy in which the weight of political power is transferred from government to the citizen (Morris, 2018).

In Estonia, the power-knowledge regime is characterized by centralization, which is the condition for a firm national e-government policy, and within this policy, an image of the unique Estonian citizenry is produced. The Estonian moral citizen who emerges out of egovernment is de-politicized and detached from a social context on the one hand, and strongly politicized and attached to a specific ethno-national community on the other (Björklund, 2016).

This optimistic view of e-democracy is not shared by all (Toots, Kalvet, and Krimmer, 2016). Singapore tells a different story about democracy and e-government. Morris (2018) states that the Estonian model is only transferable if the government of the other country is willing to deal with total transparency and accountability, because e-Estonia is a new form of democracy, where the power goes back to the people.

The cases of Estonia and Singapore prove e-government is possible in small nations. Actually, small nations might be in an advantageous position. For e-government the develop leadership and vision are conditio sine qua non. Government must take the lead, and there must be a coalition with the private sector. Education must be a priority. A technical infrastructure and legal framework must be put in place. E-government requires a specific mindset: it is about a culture and about human relationships (Heller, 2018). According to Ehasoo (2017), it is all about trust in government and transparency of government and others. Currently these conditions are lacking in Curaçao.

\section{References}

Anthes, G., 2015. Estonia: a model for e-government. Communications of the ACM, 58(6), pp. 18-20.

Björklund, F., 2016. E-government and moral citizenship: The case of Estonia. Citizenship studies, 20(6-7), pp. 914931.

Castells, M., 1996. The Rise of the Network Society. The Information Age: Economy, Society, and Culture Volume I (Information Age Series). London: Blackwell.

Dimitra Karantzeni, Dimitris G. Gouscos, (2013) "eParticipation in the EU: Re-focusing on social media and young citizens for reinforcing European identity", Transforming Government: People, Process and Policy, Vol. 7 Issue: 4 , pp. 477-500, https://doi.org/10.1108/TG-01-2013-0003

Drechsler, W., 2018. e-voting in Estonia. Trames, [online] p. Available at: https://www.academia.edu/7813796/evoting_in_Estonia [Accessed 6 Nov. 2018].

e-Estonia. (2018). e-Estonia - We have built a digital society and so can you. [online] Available at: https://eestonia.com/ [Accessed 10 Nov. 2018].

Ehasoo, E. (2017). Case Study: How Estonia became the global digital leader and what businesses can learn from it. [online] Digital Innovation. Available at: https://blog.rubiksdigital.com/how-estonia-became-the-global-digitalleader-83e1ff576f36?fbclid=IwAR0ZRglPxEB6xvYL2avyNk9WcmbCJk9xaxkd6_lCeMwpoMrTXlkkl6yeD_w [Accessed 4 Jan. 2019].

Giest, S. (2018). Country Brief: Estonia. [online] Academia.edu. Available at:

https://www.academia.edu/1400744/Country_Brief_Estonia [Accessed 6 Dec. 2018]. 
Goede, M., 2018. Curaçao: Smart Nation-From Smart city to Sage society. Archives of Business Research, 6(3).

Heller, N. (2017). Estonia, the Digital Republic. [online] The New Yorker. Available at: https://www.newyorker.com/magazine/2017/12/18/estonia-the-digital-republic [Accessed 30 Nov. 2018 ]. Ionescu, L., 2015. The role of e-government in curbing the corruption in public administration. Economics, Management and Financial Markets, 10(1), p. 48.

Jaffe, E., 2016. Save Time and Improve your Marks with CiteThisForMe, The No. 1 Citation Tool. [online] Cite This For Me. Available at: http://www.citethisforme.com/ [Accessed 20 Apr. 2016].

Keen, A. (2018). Where in the world will you find the most advanced e-government? Estonia.. [online] ideas.ted.com. Available at: https://ideas.ted.com/where-in-the-world-will-you-find-the-most-advanced-e-government-estonia/ [Accessed 18 Jan. 2019].

Kristjan V., 2017. Estonian e-Government Ecosystem: Foundation, Applications, Outcomes. Retrieved from: http://pubdocs.worldbank.org/en/ 165711456838073531/WDR16-BP-Estonian-eGov-ecosystem-Vassil.pdf

Maaten, E., 2004. Towards remote e-voting: Estonian case. Electronic Voting in Europe-Technology, Law, Politics and Society, 47, pp. 83-100.

Martens, T., 2010. Electronic identity management in Estonia between market and state governance. Identity in the Information Society, 3(1), pp. 213-233.

Menkhoff, T. (2018). Lessons from two Smart Nations: Germany \& Estonia. [online] SGSME.SG. Available at: https://www.sgsme.sg/news/lessons-two-smart-nations-germany-estonia [Accessed 18 Jan. 2019 ].

Morris, G. (2018). Estonia answers Plato: e-democracy!. [online] Estonian World. Available at: http://estonianworld.com/opinion/estonia-answers-plato-e-democracy/ [Accessed 24 Jul. 2018].

Nica, E., 2015. Public Administration as a Tool of Sustainable Development. Journal of Self-Governance and Management Economics, 3(4), pp. 30-36.

Scott, M., DeLone, W. and Golden, W., 2016. Measuring eGovernment success: a public value approach. European Journal of Information Systems, 25(3), pp. 187-208.

Sikkut, S. (n.d.). e-Estonia: building a digital government.

Taagepera, R., 2018.Estonia: Return to independence. Routledge.

Tham, I. (2018). Estonia's cyber lessons for Singapore. [online] The Straits Times. Available at: https://www.straitstimes.com/opinion/estonias-cyber-lessons-for-singapore [Accessed 18 Jan. 2019].

Toots, M., Kalvet, T. and Krimmer, R., 2016, September. Success in eVoting-success in eDemocracy? The Estonian paradox. In International Conference on Electronic Participation (pp. 55-66). Springer, Cham.

Tiik, M. and Ross, P., 2010. Patient opportunities in the Estonian electronic health record system. Stud Health Technol Inform, 156, pp. 171-7.

Urban, M. (2018). Abandoning Silos: Key Takeaways. [online] Academia.edu. Available at: https://www.academia.edu/37959844/Abandoning_Silos_Key_Takeaways [Accessed 14 Dec. 2018].

World Bank. (2018). e-Estonia: The Making of An Information Age Society. [online] Available at: http://www.worldbank.org/en/events/2014/05/20/e-estonia-the-making-of-an-information-age-society [Accessed 30 Nov. 2018]. 